\title{
Skin ulcers in systemic sclerosis - etiopathogenesis, prophylaxis and treatment
}

\section{Owrzodzenia skóry w twardzinie układowej - etiopatogeneza, profilaktyka i leczenie}

\author{
Anna Lis-Święty \\ Department of Dermatology, Medical University of Silesia, Katowice, Poland \\ Katedra i Klinika Dermatologii Śląskiego Uniwersytetu Medycznego w Katowicach, Polska
}

Dermatol Rev/Przegl Dermatol 2018, 105, 509-522

DOI: https://doi.org/l0.5। |4/dr.2018.78072

\author{
CORRESPONDING AUTHOR/ \\ ADRES DO KORESPONDENCJI: \\ dr hab. n. med. Anna Lis-Święty \\ Katedra i Klinika \\ Dermatologii \\ Śląski Uniwersytet \\ Medyczny w Katowicach \\ ul. Francuska 20/24 \\ 40-027 Katowice, Polska \\ tel.: +48 602720948 \\ e-mail: annadlis@neostrada.pl
}

\begin{abstract}
Skin ulcers are a frequent complication of systemic sclerosis. Digital ulcers are present in almost $30 \%$ of patients with limited systemic sclerosis and in $60 \%$ of patients with diffuse systemic sclerosis. Digital ulcers usually develop on the fingertips, over the extensor surface of the joints and from pre-existing calcinosis. Among the mechanisms considered to be responsible for the development of ulcers at the digital tips, one is related to the microvasculopathy and an increased production of vasoconstrictors; the other is related to the existence of thrombosis. Severe skin sclerosis is more frequent in patients with ulcers at the extensor surface of joints. Lower limb ulcers, although not common, have a multifactorial pathogenesis and are therefore the most difficult to manage. The management of systemic sclerosis ulcers involves screening for complications, promoting healing and preventing recurrences. The article discusses non-pharmacological, pharmacological and surgical treatment.
\end{abstract}

\section{STRESZCZENIE}

Owrzodzenia skóry są częstym powikłaniem twardziny układowej. W obrębie paliczków stwierdza się je u 30\% chorych na ograniczoną twardzinę układową i u 60\% chorych na uogólnioną twardzinę układową. Owrzodzenia paliczków zwykle tworzą się na opuszkach, nad wyprostnymi powierzchniami stawów i w obrębie ognisk wapnicy skóry. Do mechanizmów odpowiedzialnych za rozwój owrzodzeń opuszek, oprócz mikrowaskulopatii i produkcji substancji nasilających skurcz naczyń, należy zakrzepica naczyń. Owrzodzeniom nad wyprostnymi powierzchniami stawów częściej towarzyszy nasilone stwardnienie skóry. Owrzodzenia kończyn dolnych, chociaż rzadkie, ze względu na wieloczynnikową patogenezę są najtrudniejsze do leczenia. Postępowanie $\mathrm{w}$ owrzodzeniach $\mathrm{w}$ przebiegu twardziny układowej obejmuje wczesne wykrywanie powikłań, przyspieszenie procesu gojenia i zapobieganie nawrotom. W artykule omówiono działania niefarmakologiczne, leczenie farmakologiczne i chirurgiczne.

Key words: systemic sclerosis, Raynaud phenomenon, digital ulcers, calcinosis cutis, leg ulcers.

Słowa kluczowe: twardzina układowa, objaw Raynauda, owrzodzenia paliczków, wapnica skóry, owrzodzenia podudzi. 


\section{INTRODUCTION}

Systemic sclerosis (SSc) is a connective tissue disease, whose clinical presentation is largely connected to vascular disorders and characteristic microvasculopathy [1]. Raynaud's phenomenon is usually the first SSc symptom that involves fingers and toes. When exposed to cold temperatures, stress, or other factors, a reversible arteriolar spams in fingers and capillary dilatations appear that are accompanied by skin turning white, blue or red what is connected with a sensation of burning or severe pain. Further course of the disease involves development of distal phalangeal ulcers located at fingertips that are secondary to microvasculopathy. In $40 \%$ of cases they are observed within the first year, and in $70 \%$ within 5 years from the moment of SSc clinical presentation other than Raynaud's phenomenon [2]. They appear in $30 \%$ of patients with limited SSc (ISSc) and in almost $60 \%$ of patients suffering from diffuse SSc (dSSc) [3-5]. Digital ulcers appear more often in male patients and smokers, in whom Raynaud's phenomenon appeared shortly before SSc diagnosis, Scl-70 antibodies are confirmed, acute-phase proteins concentration is elevated, or who suffer from pulmonary hypertension [6]. Patients, who have had Raynaud's phenomenon for over 4 years, are in a lower risk group for developing ulcers in this part (reduction with $60 \%$ ) [7]. In patients who have had Scl-70 antibodies detected, ulcers of distal phalanges develop about 5 years before as compared with patients with positive anti-centromere antibodies [8]. It should be emphasized that evaluation of fingertip ulcers has a significant prognostic meaning for the SSc course. Confirmation of these may indicate involvement of internal organs and shortened survival (odds ratio (OR) 1.53) [9]. Therefore, they are classified as a special variation and separated from digital ulcers that may be found also over bony prominences of fingers, or appear in scar tissue and calcinosis cutis foci [10, 11]. The two latter variations are less often described than fingertip ulcers, however, according to some reports the incidence of ulcers on dorsal surfaces of fingers is similar to fingertip ulcers (it equalled $6 \%$ ) [12]. Moreover, both variations of ulcerations caused similar limitations to hand dexterity [12]. Furthermore, one paper reported ulcerations found on dorsal surface of fingers in $30 \%$ of patients with SSc [10]. A common problem in SSc, affecting about $25 \%$ of patients, is also a build-up of calcium deposits in skin and subcutaneous tissue [13]. Nodules, varying in size and shape, are observed in places exposed to injuries, especially on hands (distal phalanges), feet, elbows, and knees. In one of the studies, the time elapsing from the beginning of SSc to appearance of calcinosis amounted to 7.5 years on average [14]. The

\section{WPROWADZENIE}

Twardzina układowa (systemic sclerosis - SSc) jest chorobą tkanki łącznej, której obraz kliniczny wiąże się głównie z zaburzeniami naczyniowymi i charakterystyczną mikrowaskulopatią [1]. Objaw Raynauda jest zwykle pierwszym symptomem SSc, który pojawia się najczęściej w obrębie palców rąk i stóp. Pod wpływem zimna, stresu lub innych czynników dochodzi do odwracalnego skurczu tętniczek palców i rozszerzenia kapilar, którym towarzyszy zblędniecie, zasinienie i zaczerwienienie skóry połączone z uczuciem pieczenia lub silnego bólu. W dalszym przebiegu choroby na podłożu mikrowaskulopatii rozwijajają się owrzodzenia paliczków dystalnych zlokalizowane na opuszkach. W ponad $40 \%$ przypadków obserwuje się je już w pierwszym roku, a w ponad 70\% przypadków w ciągu 5 lat od momentu klinicznej manifestacji SSc innej niż objaw Raynauda [2]. Pojawiają się u 30\% pacjentów z SSc z ograniczonymi stwardnieniami skóry (limited $S S c-1 S S c$ ) i u prawie $60 \%$ z odmianą uogólnioną (diffuse SSc - dSSc) [3-5]. Częściej owrzodzenia opuszek palców rąk mają pacjenci płci męskiej oraz palący papierosy, u których objaw Raynauda pojawił się krótko przed rozpoznaniem SSc, mający przeciwciała Scl-70, podwyższone stężenie białek ostrej fazy i nadciśnienie płucne [6]. U pacjentów z objawem Raynauda powyżej 4 lat występuje mniejsze ryzyko tworzenia owrzodzeń w tej lokalizacji (redukcja o 60\%) [7]. U chorych, u których wykrywa się przeciwciała Scl-70, owrzodzenia paliczków dystalnych rozwijają się ok. 5 lat wcześniej niż u pacjentów z dodatnimi przeciwciałami antycentromerowymi [8]. Należy podkreślić, że ocena owrzodzeń na opuszkach palców ma istotne znaczenie prognostyczne dla przebiegu SSc. Ich stwierdzenie może wskazywać na zajęcie narządów wewnętrznych i skrócony czas przeżycia (iloraz szans (odds ratio - OR) 1,53) [9]. Dlatego klasyfikuje się je jako szczególną odmianę i wyodrębnia wśród owrzodzeń paliczków, które mogą lokalizować się także nad wyniosłościami kostnymi palców lub tworzyć się w bliznach i ogniskach wapnicy skóry $[10,11]$. Te dwie ostatnie odmiany opisywane są rzadziej niż owrzodzenia opuszek, chociaż według niektórych doniesień zachorowalność na owrzodzenia powierzchni grzbietowych palców była podobna jak na owrzodzenia opuszek (wynosiła 6\%) [12]. Obie odmiany owrzodzeń powodowały też podobne ograniczenia sprawności rąk [12]. Ponadto w jednej z publikacji owrzodzenia powierzchni grzbietowej palców stwierdzono u 30\% chorych na SSc [10]. Częstym problemem w SSc, dotyczącym ok. 25\% pacjentów, jest także odkładanie się złogów wapnia w skórze i tkance podskórnej [13]. Guzki różnej wielkości i kształtu stwierdza się w miejscach narażonych na urazy, zwykle na dłoniach (paliczki dystalne), stopach, łokciach i kolanach. Czas od początku SSc do pojawienia się 
risk of developing fingertip ulcers in connection to build-up of calcium deposits is high (OR 3.7) [13]. Furthermore, in $55 \%$ of skin calcifications, patients suffered also from ulcerations of other regions [15]. A special attention should be paid to the fact that about $4-6 \%$ of SSc patients suffer from lower extremity ulcers with heterogenic aetiology [16]. They are usually observed in patients who have been suffering from SSc for numerous years. In $70 \%$ of cases, lower extremity ulcers are bilateral [16]. The SSc patients constitute $2.35 \%$ of all patients with chronic lower extremity ulcers [17]. Lower leg ulcers are especially difficult to treat in SSc.

\section{ETIOPATHOGENESIS}

Fingertip ulcers are influenced by a number of factors: micro-injuries, acroscleroderma, xerosis cutis, smoking, which may increase the risk of complications in SSc patients even over threefold (including, the necessity to undergo an IV prostanoid therapy, surgical intervention - removal of necrosis or amputation of phalanges) [18]. Fingertip ulcers develop as a result of ischaemia connected to arteriolar spasm, proliferative and obliterative lesions, and vascular thrombosis. Ulcers over bony prominences are rather a consequence of repeated micro-injuries as well as constricted healing of atrophied, fibrotic, and poorly-vascularised skin. Digital ulcers may also appear in calcinosis cutis foci, which are a result of buildup of calcium deposits in affected tissues with normal calcium and phosphate concentrations in serum (dystrophic skin calcifications). Pathophysiology of this phenomenon is poorly known and probably connected to chronic inflammation and tissue hypoxia [19]. However, in pathogenesis of every variation of digital ulcers the most important role may be attributed to scleroderma microvasculopathy. It is assumed that structural vessel impairment is a consequence of an abnormal process of forming new and rebuilding the existing vessels - impaired vasculo- and angiogenesis. Classification of microvasculopathy in SSc includes two categories of lesions: destructive, as well as proliferative and obliterative [20]. Progressive atrophy of capillaries leads to tissue hipoxy and fibroblast activation. Proliferation of endothelial cells and pericytes/smooth muscle cells of vascular walls cause occlusion of arteriolae and small arteries. Proliferative and obliterative microvasculopathy develops slowly and sub-clinically. Structural lesions are concurrently accompanied by impairment in epithelial functions, coagulation/fibrinolysis, cytokine expression, their receptors, and adhesion molecules. The totality of it is responsible for an ongoing process of inflammation and fibrosis, and consequently, for skin and organ lesions in SSc. wapnicy w jednym z badań wynosił średnio 7,5 roku [14]. Ryzyko rozwoju owrzodzeń opuszek palców w związku z odkładaniem złogów wapnia było duże (OR 3,7) [13]. Ponadto w 55\% przypadków zwapnień skóry pacjenci skarżyli się na owrzodzenia również innych okolic [15]. Na uwagę zasługuje fakt, że ok. 4-6\% chorych na SSc cierpi z powodu owrzodzeń kończyn dolnych o heterogennej etiologii [16]. Stwierdza się je zwykle u pacjentów z SSc o wieloletnim przebiegu. W 70\% przypadków owrzodzenia kończyn dolnych są obustronne [16]. Chorzy na SSc stanowią 2,35\% wszystkich pacjentów z przewlekłymi owrzodzeniami kończyn dolnych [17]. Owrzodzenia podudzi w SSc są szczególnie trudne do leczenia.

\section{ETIOPATOGENEZA}

Na rozwój owrzodzeń opuszek palców wpływa wiele czynników, takich jak mikrourazy, sklerodaktylia, suchość skóry, palenie papierosów, które ponadtrzykrotnie zwiększa ryzyko wystąpienia tego powikłania u chorych na SSc (w tym konieczności dożylnej terapii prostanoidami, interwencji chirurgicznej usuwania martwicy lub amputacji paliczków) [18]. Owrzodzenia na opuszkach powstają w wyniku niedokrwienia związanego ze skurczem tętniczek, zmian proliferacyjno-zarostowych i zakrzepicy naczyń. Owrzodzenia nad wyniosłościami kostnymi raczej są skutkiem powtarzających się mikrourazów i utrudnionego gojenia atroficznej, zwłókniałej, słabo unaczynionej skóry. Owrzodzenia paliczków mogą się również tworzyć w ogniskach wapnicy skóry, które są wynikiem odkładania złogów wapnia w tkankach chorobowo zmienionych przy prawidłowym stężeniu wapnia i fosforanów w surowicy (dystroficzne zwapnienia skóry). Patofizjologia tego zjawiska jest słabo poznana, prawdopodobnie związana z przewlekłym stanem zapalnym i hipoksją tkankową [19]. Jednak w patogenezie każdej odmiany owrzodzeń paliczków najważniejszą rolę należy przypisać mikrowaskulopatii twardzinowej. Przyjmuje się, że zaburzenia strukturalne naczyń są skutkiem nieprawidłowego procesu tworzenia nowych i przebudowy istniejących naczyń - upośledzonej waskulo- i angiogenezy. Klasyfikacja mikrowaskulopatii w SSc obejmuje dwie kategorie zmian - destrukcyjne i proliferacyjno-zarostowe [20]. Postępujący zanik kapilar prowadzi do hipoksji tkanek i aktywacji fibroblastów. Proliferacja komórek śródbłonka i perycytów lub mięśni gładkich ściany naczynia powoduje zamknięcie światła tętniczek i małych tętnic. Mikrowaskulopatia proliferacyjno-zarostowa rozwija się powoli i subklinicznie. Zmianom strukturalnym towarzyszą zaburzenia funkcji śródbłonka, układu krzepnięcia lub fibrynolizy, ekspresji cytokin, ich receptorów oraz cząsteczek adhezyjnych. Wszystko to odpowiada za toczący się 
Etiopathogenesis of lower extremity ulcers is usually multicausal. Prevalence of proliferative and obliterative microvasculopathy has been confirmed histopathologically [16]. Disorders in activation of the complement system, coagulation/fibrinolysis, and angiogenesis may contribute to impairment of the healing process. It should also be remembered that in over $50 \%$ of patients with lower extremity ulcers, arterial and venous insufficiency is observed [21]. Pathologies associated with great vessels are more often confirmed in patients with 1SSc [22]. Some papers draw attention to the relationship between lower extremity ulcers and detection of antiphospholipid antibodies in the patients [23]. It was shown that a considerable risk factor of lower leg ulcers is the presence of lupus anticoagulant in serum (OR 7.2) [23]. Seldom are lower extremity ulcers accompanied by systemic vasculitis if SSc is concomitant with other connective tissue diseases [24]. It is estimated that the incidence of vasculitis secondary to cryoglobulinaemia is at $2.8 \%(7 / 46)$ [25]. In the described cases, a hepatitis $\mathrm{C}$ virus (HCV)-infection was detected [25].

\section{COURSE AND COMPLICATIONS}

Digital ulcers constitute a serious problem for patients suffering from SSc. They are chronic (healing lasts $3-15$ months) and often recur (66\% of patients) despite administering vascular drugs [2]. They are painful, and exert a negative influence on both quality of life and ability to work. Almost $70 \%$ of patients with symptoms of calcinosis cutis complain about severe pain [15]. Accompanying infections, central osteitis, and digital gangrene contribute to treatment resistance and chronic ulcers. According to recent reports, infections were confirmed in over $2 / 3$ of patients $[8,26]$. The infection was most frequently caused by Staphylococcus aureus [27]. Approximately $25 \%$ of digital ulcer cases were complicated with an infection with intestinal bacteria (especially Escherichia coli and Enterococcus faecalis) [27]. Often, the infection involved also bones and marrow (42\%) [28]. Despite the treatment, finger gangrene was observed in $22.6 \%$ of patients [2]. This complication was more common in patients with dSSc, probably due to involvement of great vessels [10]. Other factors that delay the healing process include oedema of surrounding tissues, persisting necrotic foci covered in eschars, location over bony prominences, tendons [10]. Ulcers connected with calcinosis heal considerably longer [10]. According to studies of Amanzi et al., an average time of healing for these types of ulcers equals 93.6 days, whereas it is 76.2 days in case of fingertip ulcers [10]. Prolonged healing is a great ther- proces zapalenia i włóknienia, a w efekcie za zmiany skórne i narządowe w SSc.

Etiopatogeneza owrzodzeń kończyn dolnych jest zwykle wieloczynnikowa. Występowanie mikrowaskulopatii proliferacyjno-zarostowej potwierdzono histopatologicznie [16]. Zaburzenia aktywacji układu dopełniacza, krzepnięcia lub fibrynolizy i angiogenezy mogą się przyczyniać do upośledzenia procesu gojenia. Należy także pamiętać, że u ponad $50 \%$ chorych z owrzodzeniami kończyn dolnych obserwuje się niewydolność naczyń tętniczych i żylnych [21]. Patologię związaną z dużymi naczyniami stwierdza się częściej $\mathrm{u}$ chorych na 1SSc [22]. W niektórych doniesieniach zwraca się uwagę na związek owrzodzeń kończyn dolnych z wykrywaniem $u$ chorych przeciwciał antyfosfolipidowych [23]. Wykazano, że znaczącym czynnikiem ryzyka owrzodzeń podudzi jest obecność w surowicy antykoagulantu toczniowego (OR 7,2) [23]. Rzadziej owrzodzeniom kończyn dolnych towarzyszy układowe zapalenie naczyń, jeżeli SSc wspóistnieje z innymi chorobami tkanki łącznej [24]. Częstość występowania zapalenia naczyń w przebiegu krioglobulinemii szacuje się na 2,8\% (7/46) [25]. W opisanych przypadkach wykryto zakażenie wirusem zapalenia wątroby typu C (hepatitis C virus - HCV) [25].

\section{PRZEBIEG I POWIKŁANIA}

Owrzodzenia paliczków stanowią poważny problem u chorych na SSc. Mają przewlekły przebieg (gojenie trwa 3-15 miesięcy) i często nawracają (u 66\% chorych) pomimo stosowania leków naczyniowych [2]. Są bolesne, ujemnie wpływają na jakość życia i zdolność do pracy. Na silne dolegliwości bólowe skarży się prawie 70\% pacjentów z objawami wapnicy skóry [15]. Do oporności na leczenie i przewlekłego przebiegu owrzodzeń przyczyniają się towarzyszące infekcje, zapalenie kości i szpiku, zgorzel paliczków. Według ostatnich doniesień infekcje stwierdzano u ponad $2 / 3$ pacjentów $[8,26]$. Zakażenie było najczęściej powodowane przez Staphylococcus aureus [27]. Około $25 \%$ przypadków owrzodzeń paliczków było powikłane infekcją bakteriami jelitowymi (zwłaszcza Escherichia coli i Enterococcus faecalis) [27]. Zakażenie często obejmowało także kość i szpik (42\%) [28]. Pomimo leczenia zgorzel palców obserwowano u $22,6 \%$ pacjentów [2]. Częściej powikłanie to występowało u chorych na dSSc, prawdopodobnie w związku z zajęciem dużych naczyń [10]. Do innych czynników opóźniających proces gojenia zalicza się: obrzęk okolicznych tkanek, utrzymywanie się ognisk martwicy pokrytych strupem, lokalizację nad wyniosłościami kostnymi i ścięgnami [10]. Znacznie dłużej goją się owrzodzenia związane z wapnicą [10]. Według badań Amanziego i wsp. średni czas gojenia tego typu owrzodzeń wynosił 93,6 dnia, podczas gdy w owrzodzeniach opu- 
apeutic problem in lower extremity ulcers. These ulcers are often complicated by infections and may require amputating a given extremity [29]. It especially concerns patients, in whom coexistence of cryoglobulinaemia and vasculitis is secondary to HCV-infection [25].

\section{DIAGNOSTICS AND MONITORING}

An interview is the most important part of a diagnostic process for patients suffering from SSc with fingertip ulcers. The interview should include risk factors for development of ulcers: thrombotic events, lipid disorders, dehydration, injuries, neoplasms, nicotinism, stress, taking vasoconstrictors and corticosteroids. During a physical examination an attention should be paid to site, depth, and presence of fibrin, granulation tissue, calcium deposits, necrotic and gangrenous tissues. Intensified pain and purulent secretion indicate a concomitant infection. Gangrenous ulcers may be very deep with accompanying oedema of the surrounding tissues. Central osteitis may be diagnosed via a radiography examination, or best via an magnetic resonance imaging (MRI) technique that allows for early diagnosis due to high sensitivity [30]. Skin calcifications are usually visible to the naked eye and easy to evaluate upon palpation. When in doubt, imaging may be performed to confirm the diagnosis. Radiography is recommended as a technique of choice. Computed tomography (CT) and MRI may be also useful when evaluating the lesions. Moreover, ultrasound, multidetector CT and dual-energy CT have also exhibited high sensitivity [30].

Patients with fingertip ulcers, which may be related to ischaemia secondary to great vessel lesions, should undergo a Doppler ultrasound exam or angiography [31]. Examinations of arterial and vascular systems are necessary for all patients with lower extremity ulcers. Decreased values of ankle-brachial index may indicate a peripheral artery disease in patients with toe ulcers [32]. Accompanying vasculitis or coagulopathy should also be considered in patients with an overlap syndrome. It is recommended to determine antiphospholipid antibodies and clotting factors (genetic disorders), especially in cases of lower extremity ulcers.

To evaluate the risk for developing ulcers on fingertips and monitor a patient with Raynaud's phenomenon the following are used: nailfold capillaroscopy, thermography scans, and determination of immune markers. A decrease in vessel density in nailfold capillaroscopy, numerous vasodilation disorders in thermography imaging, and presence of Scl70 antibodies are considered to be disadvantageous prognostic markers. szek palców 76,2 dnia [10]. Długotrwałe gojenie jest dużym problemem terapeutycznym w owrzodzeniach na kończynach dolnych. Owrzodzenia te często są powikłane infekcjami i mogą spowodować konieczność amputacji kończyny [29]. Dotyczy to szczególnie pacjentów, u których współistnieje krioglobulinemia i zapalenie naczyń w przebiegu zakażenia HCV [25].

\section{DIAGNOSTYKA I MONITOROWANIE}

Badanie podmiotowe jest najważniejszą częścią procesu diagnostycznego u chorego na SSc z owrzodzeniami opuszek. W wywiadzie należy uwzględnić czynniki ryzyka rozwoju owrzodzeń, takie jak stany zakrzepowe, zaburzenia lipidowe, odwodnienie, urazy, nowotwory, nikotynizm, stres, zażywanie leków obkurczających naczynia, glikokortykosteroidów. Podczas badania fizykalnego powinno się zwrócić uwagę na lokalizację, głębokość, obecność włóknika, ziarniny, złogów wapnia, tkanek martwiczych i zgorzelinowych. Nasilone dolegliwości bólowe i ropna wydzielina wskazują na współistniejące zakażenie. Owrzodzenia zgorzelinowe mogą być bardzo głębokie, może im towarzyszyć obrzęk okolicznych tkanek. Zapalenie kości i szpiku można zdiagnozować za pomocą badania radiologicznego, a najlepiej techniką rezonansu magnetycznego (magnetic resonance imaging - MRI), umożliwiającą wczesne rozpoznanie ze względu na wysoką czułość [30]. Zwapnienia skóry są zazwyczaj widoczne gołym okiem i łatwe do oceny palpacyjnej. W razie wątpliwości w celu potwierdzenia diagnozy można wykonać badania obrazowe. Jako technikę z wyboru rekomenduje się badanie radiologiczne. W ocenie zmian mogą być przydatne ponadto tomografia komuterowa (computed tomography - CT) i MRI. Dobrą czułością cechowały się także utrasonografia, wielorzędowa CT (multidetector CT) i dwuenergetyczna CT (dual-energy CT) [30].

U chorych z owrzodzeniami opuszek palców podejrzanymi o związek z niedokrwieniem w przebiegu zmian dużych naczyń należy wykonać badanie USG metodą Dopplera lub angiograficzne [31]. Badania układu naczyniowego tętniczego i żylnego są konieczne u wszystkich pacjentów z owrzodzeniami na kończynach dolnych. Na chorobę tętnic obwodowych u pacjentów $\mathrm{z}$ owrzodzeniami palców stóp może wskazywać zmniejszona wartość wskaźnika kostkowo-ramiennego [32]. U pacjentów z zespołami nakładania należy ponadto rozważyć towarzyszące zapalenie naczyń lub koagulopatię. Zaleca się oznaczenie przeciwciał antyfosfolipidowych i czynników krzepnięcia (zaburzenia genetyczne), zwłaszcza w przypadkach owrzodzeń kończyn dolnych.

Do oceny ryzyka rozwoju owrzodzeń na opuszkach palców i monitorowania pacjentów z objawem Raynauda wykorzystuje się badanie kapilaroskopowe wałów 


\section{CHANGING THE LIFESTYLE AND OTHER PROPHYLACTIC ACTIVITIES}

Treatment of digital ulcers requires a holistic approach. Education of patients and non-pharmacological methods exert a significant influence on primary and secondary prevention. Patients' attention should be focused on avoiding factors that might intensify Raynaud's phenomenon, such as the cold and stress. Protection against being exposed to low temperatures should include appropriate precautions (warm clothes, gloves) during wintertime, changing atmospheric conditions during other seasons, or using a fridge (at home, while doing the shopping). It is not recommended to work in an environment when one is exposed to the cold, vibrations, and finger injuries. The patients should care about their hands by using barrier creams and protect their skin over bony prominences especially. Co-operation with a psychologist may have a beneficial influence on alleviating negative products of stress. Stress reduction techniques, relaxation, biofeedback, or acupuncture may be recommended, however, there is no sufficient evidence confirming their efficacy. Due to frequent anxiety and depression, some patients may require psychiatric help and administration of antidepressants or anxiolytic drugs. Making patients aware that nicotine has harmful effects is of the essence - observing the prohibition to smoke is absolutely necessary. The patients should limit their coffee consumption. Also vasodilators ( $\beta$-blockers), drugs against migraine (sumatriptan, ergotamine), contraceptives, antineoplastic drugs (cisplatin, vinblastine), and amphetamine exert a negative influence on Raynaud's phenomenon course. It is recommended to avoid therapy with these drugs. A physician should also know what supplements a patient is taking, whether they use vitamin $\mathrm{C}$ or $\mathrm{E}$, formulations containing evening primrose oil or ginkgo biloba. Uncontrolled use of supplementary therapies may cause potential pharmacological interactions.

\section{TOPICAL TREATMENT}

Education of patients with regard to hygiene, proper care, and topical treatment is essential for progressive healing of digital ulcers and limiting the risk of infection. It is recommended to avoid using topical antiseptics (cytotoxic effect) and antibiotics due to fast-progressing resistance to antibiotics. To clean ulcerations it is best to use a physiological saline solution. Necrotic tissues may be removed mechanically (curettage, debridement) or chemically (enzymatic, e.g. using formulations containing collagenase, papain, trypsin). Dressings are chosen depending on the paznokciowych palców, badanie termograficzne i oznaczanie markerów immunologicznych. Za niekorzystne markery prognostyczne uznaje się zmniejszenie gęstości naczyń w badaniu kapilaroskopowym, duże nasilenie zaburzeń czynności naczyniorozkurczowej w badaniu termograficznym oraz obecność przeciwciał Scl70.

\section{ZMIANA STYLU ŻYCIA I INNE DZIAŁANIA PROFILAKTYCZNE}

Leczenie owrzodzeń paliczków wymaga podejścia holistycznego. Edukacja chorych i metody niefarmakologiczne mają istotne znaczenie dla profilaktyki pierwotnej i wtórnej. Pacjentom należy zwrócić uwagę na unikanie czynników nasilających objaw Raynauda, takich jak zimno i stress. Ochrona przed ekspozycją na niską temperaturę powinna polegać na odpowiednim zabezpieczeniu (ciepły ubiór, noszenie rękawiczek) w okresie zimy, podczas zmiennych warunków pogodowych w innych porach roku lub też przy korzystaniu z lodówki (w domu, podczas zakupów). Nie zaleca się pracy zawodowej w narażeniu na chłód, wibrację i urazy palców. Pacjenci powinni pielęgnować ręce, używając kremów barierowych, i chronić skórę, szczególnie nad wyniosłościami kostnymi. Na złagodzenie negatywnego oddziaływania stresu korzystnie może wpłynąć współpraca z psychologiem. Mogą być zalecane techniki redukcji stresu, relaksacyjne, biofeedback i akupunktura, chociaż brakuje wystarczających dowodów potwierdzających ich skuteczność. Ze względu na często towarzyszący lęk i depresję część chorych może wymagać porady psychiatrycznej i wdrożenia leków przeciwdepresyjnych lub anksjolitycznych. Uświadomienie pacjentom szkodliwego działania nikotyny jest bardzo istotne, a przestrzeganie zakazu palenia bezwzględnie konieczne. Chorzy powinni ograniczyć spożycie kofeiny. Negatywny wpływ na przebieg objawu Raynauda mają leki obkurczające naczynia ( $\beta$-adrenolityki), leki na migrenę (sumatryptan, ergotamina), środki antykoncepcyjne, leki przeciwnowotworowe (cisplatyna, winblastyna), amfetamina. Wskazane jest unikanie ich stosowania. Lekarz powinien wiedzieć także, jakie suplementy zażywa pacjent, czy stosuje witaminy C i E, preparaty zawierające olej z wiesiołka, gingko biloba. Niekontrolowane stosowanie terapii komplementarnych może być przyczyną interakcji farmakologicznych.

\section{LECZENIE MIEJSCOWE}

Bardzo istotne znaczenie dla postępu gojenia owrzodzeń paliczków i ograniczenia ryzyka infekcji ma edukacja chorych dotycząca zasad higieny, właściwej pielęgnacji i leczenia miejscowego. Zaleca się 
condition of ulcerations. With dry lesions, dressings forming a moist environment (hydrocolloid or hydrogel dressings) are recommended, whereas in case of lesions with exudate, absorptive dressings should be used (hydrofiber, alginate or hydropolymer - foam dressings) [33]. Semipermeable dressings prevent a wound from becoming dry and keep the warmth, what aids the healing. Moreover, it was observed that applying a gel with vitamin $\mathrm{E}$ has beneficial effects [34]. Intralesional glucocorticosteroid injections proved to be successful in reducing inflammation associated with skin calcifications [19].

\section{SYSTEMIC TREATMENT}

\section{Vascular drugs}

The regimen basis in case of fingertip ulcers is treatment directed towards improving vascular disorders associated with Raynaud's phenomenon. However, the mechanism of vascular drugs is based mainly on dilating the vessels, what does not influence accompanying structural changes in vessels to a significant extent. Recommendations of various scientific associations indicate using calcium channel blockers (e.g. nifedipine, amlodipine), phosphodiesterase 5 inhibitors (e.g. sildenafil), angiotensin receptor antagonists, selective serotonin reuptake inhibitors, $\alpha_{1}$ adrenergic receptor blockers, angiotensin convertase inhibitors, and topical nitrates (e.g. nitroglycerin) as the first-line treatment for patients suffering from SSc with Raynaud's phenomenon [33, 35, 36]. In case pain progresses and ulcers continue to appear, it is necessary to optimize the vascular therapy. Treatment modifications should depend on intensity of symptoms and be based on increasing the dose of already used drug, or adding or substituting the drug with an alternative one that dilates or inhibits vasospasms. It is recommended to change a given therapy every 3-6 weeks if there are no clinical improvements [37]. Application of phosphodiesterase 5 inhibitors (PDE-5) is especially justified [38, 39]. As soluble guanylyl cyclase stimulators responsible for cGMP production, these drugs lead to an increase of nitric oxide (NO) concentration. A decrease in NO production as a result of endothelial cell dysfunction is a characteristic feature of microvasculopathy in sclerosis. The factor inhibits proliferation of vascular smooth muscle cells and provokes them to expand.

If there are no effective oral therapies, in resistant Raynaud's phenomenon or progressive trophic lesions on fingertips, it is recommended to implement intravenous prostanoid infusions (iloprost, alprostadil), especially during cold seasons. Intensive unikanie antyseptyków stosowanych miejscowo (efekt cytotoksyczny) i antybiotyków ze względu na szybko rozwijającą się antybiotykooporność. Do oczyszczania owrzodzeń najlepiej używać roztworu soli fizjologicznej. Tkanki martwicze można usunąć mechanicznie (łyżeczkowanie, chirurgiczne opracowanie) lub chemicznie (enzymatycznie, np. stosując preparaty zawierające kolagenazę, papainę, trypsynę). Opatrunki dobiera się w zależności od stanu owrzodzenia. Przy suchych zmianach najlepiej zastosować opatrunki tworzące wilgotne środowisko (hydrokoloidowe, hydrożelowe), natomiast w owrzodzeniach z wysiękiem - opatrunki o właściwościach chłonnych (hydrowłókniste - typu hydrofiber, alginianowe, hydropolimerowe - piankowe) [33]. Półprzepuszczalne opatrunki zapobiegają wysychaniu rany i utrzymują ciepło, co sprzyja gojeniu. Korzystny wpływ na postęp gojenia owrzodzeń paliczków obserwowano po zastosowaniu żelu z witaminą E [34]. W redukcji stanu zapalnego związanego ze zwapnieniami skóry skuteczne były doogniskowe iniekcje glikokortykosteroidów [19].

\section{LECZENIE OGÓLNOUSTROJOWE}

\section{Leki naczyniowe}

Podstawą postępowania w owrzodzeniach opuszek jest leczenie ukierunkowane na poprawę zaburzeń naczyniowych związanych z objawem Raynauda. Mechanizm działania leków naczyniowych opiera się jednak głównie na rozszerzeniu naczyń, bez istotnego wpływu na towarzyszące zmiany strukturalne naczyń. Rekomendacje różnych towarzystw naukowych wskazują na stosowanie antagonistów kanału wapniowego (np. nifedypina, amplodypina), inhibitorów fosfodiesterazy typu 5 (np. sildenafil), antagonistów receptora angiotensyny, selektywnych inhibitorów wychwytu zwrotnego serotoniny, antagonistów receptorów $\alpha_{1}$-adrenergicznych, inhibitorów konwertazy angiotensyny oraz miejscowych nitratów (nitrogliceryna) jako pierwszej linii terapii u chorych na SSc z objawem Raynauda [33, 35, 36]. W przypadku progresji dolegliwości i tworzenia się owrzodzeń zawsze konieczna jest optymalizacja terapii naczyniowej. Modyfikacja leczenia powinna zależeć od nasilenia objawów i polegać na zwiększeniu dawki już stosowanego leku, dodaniu do niego lub zastąpieniu go innym, alternatywnym lekiem rozszerzającym naczynia lub hamującym skurcz naczyń. Zmianę terapii zaleca się co 3-6 tygodni, jeżeli nie obserwuje się poprawy klinicznej [37]. Szczególne uzasadnienie ma stosowanie inhibitorów fosfodiesterazy 5 (PDE-5) [38, 39]. Jako stymulatory rozpuszczalnej cyklazy guanylowej odpowiedzialnej za produkcję cGMP leki te prowadzą do zwiększenia stężenia tlen$\mathrm{ku}$ azotu (NO). Zmniejszenie produkcji NO w wyni- 
treatment in hospital is always required in cases of critical (acute) ischaemia of distal phalanges - diagnosis should be made as soon as possible. In case of recurring digital ulcers, intravenous therapeutic applications should be repeated if oral prostanoid are not too effective [38]. In patients with multiple digital ulcers, whose condition failed to improve after the therapy with calcium channel blockers, PDE-5 inhibitors and prostanoids, it is recommended to administer endothelin-1 (ET-1) receptor blocker, bosentan [38]. Endothelin-1 that induces fibroproliferative changes in vascular walls is the most important mediator responsible for the development of proliferative and obliterative microvasculopathy in SSc. Decreasing the number of new fingertip ulcers post iloprost IV infusions and bosentan has been confirmed in randomized clinical studies and meta-analyses [38]. Furthermore, clinical trials with PDE-5 inhibitors exerted a positive influence on healing the fingertip ulcers [38]. Vascular drugs play also an important role in treating skin ulcers in other sites than fingertips. In patients with ulcers over bony prominences and lower extremities a considerable improvement was observed after the treatment with bosentan [39-42].

Side effects associated with the use of vascular drugs are very common. The therapy should be run with extreme caution, starting with low drug doses, which can be gradually increased if tolerated well (table 1).

\section{Antithrombotic and antiaggregant drugs}

Assuming that SSc involves coagulation and fibrinolysis balance disorders, it is indicated to administer antithrombotic and antiaggregant drugs. Aspirin and clopidogrel should be recommended to all patients with fingertip pad ulcers or peripheral arterial insufficiency [33]. Due to common coexistence of gastrointestinal disorders, clopidogrel treatment is preferred [33]. A short heparin therapy should be implemented in cases of acute ischaemia or intensified finger ischaemia [33]. Results of using low-molecular-weight heparin in SSc patients with lower leg ulcers were also promising [29]. Using sulodexide is a form of preventing the risk of vascular thrombosis in SSc [35]. Antithrombotic drug activity consists in inhibiting factor Xa and blood platelet aggregation, as well as activating the fibrinolytic system. The influence on factor IIa (thrombin) is little. An improvement in rheological properties of blood is associated with decreasing the fibrinogen concentration in plasma. Long-lasting treatment involving drugs inhibiting blood platelet aggregation or oral anticoagulants in SSc depends on individual indications, e.g. in patients in whom circulating antiphospholipid antibodies were detected. ku zaburzenia funkcjonowania komórek śródbłonka jest charakterystyczną cechą mikrowaskulopatii twardzinowej. Czynnik ten hamuje proliferację komórek mięśni gładkich naczyń i wywołuje ich rozkurcz.

$\mathrm{W}$ razie braku skuteczności terapii doustnych, w opornym na leczenie objawie Raynauda lub przy progresji zmian troficznych na opuszkach palców zaleca się wdrożenie dożylnych wlewów prostanoidów (iloprost, alprostadyl), zwłaszcza w chłodnych porach roku. Intesywne leczenie w warunkach hospitalizacji jest zawsze wymagane w stanach krytycznego (ostrego) niedokrwienia paliczków dystalnych - rozpoznanie powinno być ustalone jak najwcześciej. W przypadkach nawracających owrzodzeń paliczków dożylne kursy terapeutyczne należy powtarzać. Prostanoidy stosowane doustnie okazały się mało skuteczne [38]. U chorych z mnogimi owrzodzeniami paliczków, u których po leczeniu antagonistami kanału wapniowego, inhibitorami PDE-5 i prostanoidami nie osiągnięto poprawy, wskazane jest podanie antagonistów receptora endoteliny 1 (ET-1), bozentanu [38]. Endotelina 1, która indukuje zmiany fibroproliferacyjne w ścianach naczyń, jest najważniejszym mediatorem odpowiedzialnym za rozwój mikrowaskulopatii proliferacyjno-zarostowej w SSc. Zmniejszenie liczby nowych owrzodzeń opuszek po leczeniu dożylnymi wlewami iloprostu oraz bozentanem potwierdzono $\mathrm{w}$ randomizowanych badaniach klinicznych i metaanalizach [38]. Pozytywny wpływ na gojenie owrzodzeń na opuszkach wykazały próby kliniczne z zastosowaniem inhibitorów PDE-5 [38]. Leki naczyniowe odgrywają także ważną rolę w leczeniu owrzodzeń skóry w innej lokalizacji niż opuszki palców. U chorych z owrzodzeniami nad wyniosłościami kostnymi i na kończynach dolnych obserwowano znaczącą poprawę po zastosowaniu bozentanu [39-42].

Działania niepożądane leków naczyniowych są bardzo częste. Terapię należy prowadzić bardzo ostrożnie, rozpoczynając od małych dawek, które następnie przy dobrej tolerancji można stopniowo zwiększać (tab. 1).

\section{Leki przeciwzakrzepowe i antyagregacyjne}

Przyjmując, że w SSc dochodzi do zaburzenia równowagi procesów krzepnięcia i fibrynolizy, wskazane jest podawanie leków przeciwzakrzepowych i antyagregacyjnych. Kwas acetylosalicylowy lub klopidogrel powinno się zalecać wszystkim pacjentom z owrzodzeniami na opuszkach palców, martwicą palców lub obwodową niewydolnością tętniczą [33]. Ze względu na często współistniejące zaburzenia żołądkowo-jelitowe preferuje się leczenie klopidogrelem [33]. Krótkotrwałą terapię heparynami należy wdrożyć w stanach ostrego niedokrwienia lub zaostrzenia niedokrwienia palców [33]. Wyniki zastosowania preparatów heparyny drobnocząsteczkowej 
Table I. Vascular drugs recommended in prophylaxis and treatment of digital ulcers in systemic sclerosis

\begin{tabular}{|c|c|c|}
\hline Therapeutic class & Drug and dose & Most common side effects \\
\hline Calcium channel blockers & $\begin{array}{l}\text { Nifedipine } 10-20 \text { mg 3× day } \\
\text { Amlodipine 5-20 mg/day }\end{array}$ & $\begin{array}{l}\text { Tachycardia, peripheral oedema, facial } \\
\text { erythema, headaches, dizziness }\end{array}$ \\
\hline Phosphodiesterase 5 inhibitors & $\begin{array}{c}\text { Sildenafil: } 50-100 \text { mg } 2 \times \text { day } \\
\text { Tadalafil: } 20 \text { mg every second day for } \\
8 \text { weeks }\end{array}$ & $\begin{array}{c}\text { Headaches, nausea, facial erythema, } \\
\text { mandibular pain }\end{array}$ \\
\hline Angiotensin receptor antagonists & Losartan 25-100 mg/day & Dizziness, headaches \\
\hline Selective serotonin reuptake inhibitors & Fluoxetine $20 \mathrm{mg} /$ day & Insomnia, nausea, diarrhoea \\
\hline$\alpha_{1}$-Adrenergic receptor blockers & Prazosin $1-5$ mg $2 \times$ day & Collapse, dizziness \\
\hline Topical nitrates & $\begin{array}{l}2 \% \text { nitroglycerin ointment } 1 / 4-1 / 2 \\
\text { fingertip unit daily }\end{array}$ & Headaches, tachycardia, collapse \\
\hline Prostanoids & $\begin{array}{l}\text { Iloprost } 0.5-2 \mathrm{ng} / \mathrm{kg} \text { b.w./min i.v. for } \\
3-5 \text { days every } 6-8 \text { weeks } \\
\text { Alprostadil } 0.1-0.4 \mu g / k g \text { b.w./min i.v. for } \\
\text { 2-5 days approx. every } 4-6 \text { weeks }\end{array}$ & $\begin{array}{l}\text { Facial erythema, diarrhoea, headache, drop } \\
\text { in blood pressure, skin exanthema }\end{array}$ \\
\hline Endothelin receptor blockers & $\begin{array}{l}\text { Bosentan } 62.5 \mathrm{mg} 2 \times \text { day for } 4 \text { weeks, } \\
\text { then, } 125 \mathrm{mg} 2 \times \text { day for } 12 \text { or } 20 \text { weeks }\end{array}$ & $\begin{array}{l}\text { Headaches, peripheral oedema, anaemia, } \\
\text { liver damage, teratogenicity, interactions } \\
\text { with cytochrome P450 metabolized drugs }\end{array}$ \\
\hline
\end{tabular}

Tabela I. Leki naczyniowe zalecane w profilaktyce i leczeniu owrzodzeń paliczków w twardzinie układowej

\begin{tabular}{|c|c|c|}
\hline Klasa terapeutyczna & Lek i dawka & Najczęstsze objawy uboczne \\
\hline Anatagoniści kanału wapniowego & $\begin{array}{c}\text { Nifedypina 10-20 mg } 3 \text { razy dziennie } \\
\text { Amlodypina 5-20 mg/dobę }\end{array}$ & $\begin{array}{l}\text { Tachykardia, obrzęki obwodowe, rumień } \\
\text { twarzy, bóle głowy, zawroty głowy }\end{array}$ \\
\hline Inhibitory fosfodiesterazy typu 5 & $\begin{array}{c}\text { Sildenafil 50-100 mg } 2 \text { razy dziennie } \\
\text { Tadalafil } 20 \text { mg co drugi dzień przez } \\
8 \text { tygodni }\end{array}$ & $\begin{array}{c}\text { Bóle głowy, nudności, rumień twarzy, } \\
\text { ból żuchwy }\end{array}$ \\
\hline Antagoniści receptora angiotensyny & Losartan 25-100 mg/dobę & Zawroty, bóle głowy \\
\hline $\begin{array}{l}\text { Selektywne inhibitory wychwytu } \\
\text { zwrotnego serotoniny }\end{array}$ & Fluoksetyna 20 mg/dobę & Bezsenność, nudności, biegunka \\
\hline $\begin{array}{l}\text { Antagoniści receptorów } \\
\alpha_{1} \text {-adrenergicznych }\end{array}$ & Prazosyna I-5 mg 2 razy dziennie & Omdlenia, zawroty głowy \\
\hline Miejscowe nitraty & $\begin{array}{l}\text { 2\% maść nitroglicerynowa I/4-I/2 } \\
\text { jednostki opuszkowej dziennie }\end{array}$ & Bóle głowy, tachykardia, omdlenia \\
\hline Prostanoidy & $\begin{array}{l}\text { Iloprost 0,5-2 ng/kg m.c./min i.v. przez } \\
\text { 3-5 dni co 6-8 tygodni } \\
\text { Alprostadyl 0, I-0,4 } \mu \text { g/kg m.c./min i.v. } \\
\text { przez 2-5 dni co ok. 4-6 tygodni }\end{array}$ & $\begin{array}{l}\text { Rumień twarzy, biegunka, ból głowy, } \\
\text { spadek ciśnienia tętniczego, osutka skórna }\end{array}$ \\
\hline Antagoniści receptora endotelinowego & $\begin{array}{c}\text { Bozentan } 62,5 \text { mg } 2 \text { razy dziennie przez } \\
4 \text { tygodnie, następnie } 125 \text { mg } 2 \text { razy } \\
\text { dziennie przez I } 2 \text { lub } 20 \text { tygodni }\end{array}$ & $\begin{array}{c}\text { Bóle głowy, obrzęki obwodowe, } \\
\text { niedokrwistość, uszkodzenie wątroby, } \\
\text { teratogenność, interakcje z lekami } \\
\text { metabolizowanymi przez cytochrom P450 }\end{array}$ \\
\hline
\end{tabular}

\section{Statins}

Despite the fact that there is no sufficient evidence that treatment with statins is successful, administration of these drugs in complimentary therapy is worth considering. It especially regards patients with concomitant cardiovascular risk factors. Antioxidant, anti-inflammatory, and anti-fibrinotic activity of statins may alleviate disorders associated with microvasculopathy in sclerosis [43].

\section{Rituximab}

It is worth mentioning that some patients, who were resistant to digital ulcer treatment, healed af- były także obiecujące u chorych na SSc z owrzodzeniami podudzi [29]. Formą zapobiegania ryzyku wystąpienia zakrzepicy naczyń w SSc jest stosowanie sulodeksydu [35]. Działanie przeciwzakrzepowe leku polega na hamowaniu czynnika Xa i agregacji płytek krwi oraz aktywacji układu fibrynolitycznego. Wpływ na czynnik IIa (trombinę) jest niewielki. Poprawa właściwości reologicznych krwi wiąże się ze zmniejszeniem stężenia fibrynogenu w osoczu. Długotrwałe stosowanie leków hamujących agregację płytek krwi lub doustnych antykoagulantów w SSc zależy od indywidualnych wskazań, np. u chorych, u których wykrywa się krążące przeciwciała antyfosfolipidowe. 
ter rituximab was introduced [44]. The drug was also effective for 2/3 of patients with lower extremity ulcers in 1SSc with concurrent cryoglobulinaemia and vasculitis [25].

\section{Pharmacotherapy in calcinosis cutis}

Various drugs have been administered in order to decrease skin calcifications, however, therapeutic effects were described in individual or small series of cases. Despite the fact that there are no unambiguous results, calcium channel blockers are recommended as first-line drugs. Majority of the reports regard the use of diltiazem, which was recommended in 240-480 mg doses daily for the period between 1 and 12 years [14, 19]. Although the use of bisphosphonates in patients with SSc and calcinosis is justified by concomitant osteoporosis, data regarding their efficacy in reducing calcifications is insufficient [13]. Only some reports suggest a beneficial effect of treating calcinosis cutis with warfarin [14, 19]. Other drugs that may potentially inhibit build-up of calcium deposits include: minocycline, colchicine, ceftriaxone, probenecid, aluminium hydroxide, intravenous immunoglobulins, and other anti-inflammatory drugs $[15,19]$. During the treatment with rituximab, an improvement was observed within calcinosis foci and pain in the CREST syndrome [45] However, the reports include only descriptions of individual cases.

\section{Antibiotic therapy}

It should be reserved for ulcers with clinical symptoms of infections. However, this complication is common in fingertip ulcers. Then, it is recommended to commence the antibiotic therapy fast. An antibiotic needs to be chosen on the basis of an antibiogram. In cases of central osteitis, antibiotic therapy is conducted intravenously [46].

\section{Analgesic drugs}

Fingertip ulcers are extremely painful. The pain may intensify vasospasms and ischaemia by affecting adrenoreceptors. Treatment should be commenced fast. Acetaminophen is preferred, however, sometimes it is necessary to use opioid drugs. The drugs from this group should be administered with caution as they slow down the healing process [47]. A common cause for administering opioid drugs is pain associated with surgical treatment of ulcers [48].

\section{SURGICAL TREATMENT}

Surgical treatment is the best method for patients with calcinosis cutis if there is a need to remove

\section{Statyny}

Chociaż nie ma wystarczających dowodów potwierdzających skuteczność leczenia statynami, warto rozważyć podanie tych leków w terapii uzupełniającej. Dotyczy to szczególnie chorych z towarzyszącym ryzykiem sercowo-naczyniowym. Działanie antyoksydacyjne, przeciwzapalne i antyfibrotyczne statyn może łagodzić zaburzenia związane z mikrowaskulopatią twardzinową [43].

\section{Rytuksymab}

Godne uwagi jest doniesienie dotyczące wygojenia opornych na terapię owrzodzeń paliczków po zastosowaniu rytuksymabu [44]. Lek ten okazał się także skuteczny u 2/3 pacjentów z owrzodzeniami kończyn dolnych w przebiegu 1SSc współistniejącej z krioglobulinemią i zapaleniem naczyń [25].

\section{Farmakoterapia w wapnicy skóry}

W celu zmniejszenia zwapnień skóry próbowano podawać różne leki, jednak efekty terapeutyczne opisywano w pojedynczych lub małych seriach przypadków. Pomimo braku jednoznacznych wyników jako leki pierwszego wyboru proponuje się antagonistów kanału wapniowego. Najwięcej doniesień dotyczy stosowania diltiazemu, który zalecano w dawkach 240-480 mg dziennie przez 1-12 lat [14, 19]. Chociaż stosowanie bisfosfonianów u chorych na SSc i wapnicę uzasadnia współwystępująca osteoporoza, dane na temat ich skuteczności w redukcji zwapnień są niewystarczające [13]. Tylko niektóre doniesienia sugerują korzystny wpływ leczenia wapnicy skóry warfaryną $[14,19]$. Do innych leków, które mogą hamować odkładanie się złogów wapnia, należą: minocyklina, kolchicyna, ceftriakson, probenecyd, wodorotlenek glinu, immunoglobuliny stosowane dożylnie, jak również inne leki o działaniu przeciwzapalnym $[15,19]$. Podczas terapii rytuksymabem obserwowano poprawę w zakresie ustępowania ognisk wapnicy i dolegliwości bólowych w zespole CREST [45]. Doniesienia te obejmują jednak tylko opisy pojedynczych przypadków.

\section{Antybiotykoterapia}

Powinna być zarezerwowana tylko do przypadków owrzodzeń z klinicznymi objawami infekcji. W owrzodzeniach opuszek powikłanie to jest jednak częste. Zaleca się wówczas szybkie rozpoczęcie antybiotykoterapii. Antybiotyk należy dobrać na podstawie antybiogramu. W przypadkach podejrzenia zapalenia kości i szpiku antybiotykoterapię prowadzi się dożylnie [46].

\section{Leczenie przeciwbólowe}

Owrzodzenia opuszek są zwykle bardzo bolesne. Ból, wpływając na receptory adrenergiczne, może na- 
calcium deposits that are bigger in size or located deeper. Indications for surgical interventions in other cases are rare. Surgical debridement of fingertip ulcers is conducted if there were no improvements after pharmacological treatment. Similarly, if pharmacology failed in central osteitis treatment, it is required to conduct surgical debridement. In case of gangrene, it is necessary to remove necrotic tissues or amputate the finger to alleviate the pain $[2,8]$. In ulcers resistant to therapy, pain may be decreased and healing may proceed faster thanks to allogeneic skin grafts [49]. Surgical treatment of lower limb artery stenosis and venous insufficiency in patients with SSc provides worse long-term effects than in patients without SSc [50]. In spite of recreating arterial and venous system functions, ulcers remain resistant to topical treatment. Vasculopathy of small vessels is the reason behind it. Currently, due to a high percentage of side effects in patients with SSc, chest sympathectomy for Raynaud's phenomenon as well as digital ulcer prevention and treatment is not recommended. Peripheral sympathectomy may provide beneficial results [51].

\section{OTHER METHODS}

Attempts to use botulinum toxin for prevention and treatment of digital ulcers in SSc are promising [52]. However, its efficacy has not been confirmed in a placebo-controlled study yet [53]. Reports indicate positive results of treating small calcinosis foci with a $\mathrm{CO}_{2}$ laser and extracorporeal shock wave lithotripsy (ESWL) [54]. Beneficial effects of treating digital ulcers were also described after hyperbaric oxygen therapy, negative pressure therapy, acoustic wave therapy, and intermittent pneumatic compression therapy [54]. However, evaluation of efficacy of these methods is insufficient, and further studies on therapeutic effects of the methods in SSc are required.

\section{CONCLUSIONS}

Skin ulcer therapy in SSc requires an individual approach that takes into account intensity of lesions and concurrent complications. It is always based on systemic and topical treatment, including analgesic and non-pharmacological methods as well. Appropriate education and changes in lifestyle may contribute to improving treatment results and preventing recurrences. Hospitalization and treatment modifications including patient's general condition, progress of the disease and factors influencing its course, may be necessary when symptoms intensify significantly. silać skurcz naczyń i niedokrwienie. Leczenie należy wdrożyć szybko. Preferuje się podawanie acetaminofenu, czasami jednak konieczne jest stosowanie leków opioidowych. Należy zachować ostrożność podczas ordynowania leków z tej grupy, ponieważ spowalniają one proces gojenia [47]. Częstą przyczyną podania opioidów jest ból związany z chirurgicznym oczyszczaniem owrzodzeń [48].

\section{LECZENIE CHIRURGICZNE}

Postępowanie chirurgiczne jest najlepszą metodą u pacjentów $\mathrm{z}$ wapnicą skóry w przypadku potrzeby usunięcia złogów wapnia większych rozmiarów lub głębiej umiejscowionych. Wskazania do interwencji chrurgicznych w innych przypadkach są rzadkie. Oczyszczenie chirurgiczne owrzodzeń opuszek przeprowadza się, jeżeli nie uzyskano poprawy po leczeniu farmakologicznym. Podobnie w zapaleniu kości i szpiku chirurgiczne opracowanie jest niezbędne $\mathrm{w}$ razie niepowodzenia farmakoterapii. W przypadkach zgorzeli w celu zmniejszenia bólu konieczne może być usunięcie tkanek martwiczych lub amputacja palca $[2,8]$. W opornych na terapię owrzodzeniach zmniejszenie dolegliwości bólowych i przyspieszenie gojenia można osiągnąć przy użyciu allogenicznych przeszczepów skóry [49]. Leczenie operacyjne zwężeń tętnic kończyn dolnych i niewydolności żylnej u chorych na SSc daje znaczaco gorsze długoterminowe wyniki niż u pacjentów bez SSc [50]. Pomimo odtworzenia funkcji układu tętniczego i żylnego owrzodzenia są oporne na leczenie miejscowe. Przyczyną jest waskulopatia drobnych naczyń. Obecnie ze względu na duży odsetek objawów ubocznych u chorych na SSc nie rekomenduje się zabiegów sympatektomii piersiowej w zapobieganiu oraz leczeniu objawu Raynauda i owrzodzeń opuszek. Korzystny efekt można uzyskać po zastosowaniu sympatektomii obwodowej [51].

\section{INNE METODY}

Próby stosowania toksyny botulinowej w celu profilaktyki i leczenia owrzodzeń opuszek w SSc są obiecujące [52]. Jej skuteczność nie została jednak potwierdzona na podstawie badania kontrolowanego placebo [53]. Doniesienia z piśmiennictwa wskazują na pozytywne wyniki leczenia drobnych ognisk kalcynozy przy użyciu lasera $\mathrm{CO}_{2}$ oraz litotrypsji pozaustrojową falą uderzeniową (extracorporeal shock wave lithotripsy - ESWL) [54]. Opisano także korzystne efekty leczenia owrzodzeń paliczków po zastosowaniu hiperbarycznej terapii tlenem, terapii podciśnieniowej, falami akustycznymi, za pomocą przerywanego ucisku pneumatycznego [54]. Ocena skuteczności tych metod jest na razie niewystarczająca i wymagane są dalsze badania nad ich działaniem terapeutycznym w SSc. 


\section{CONFLICT OF INTEREST}

Autor declares no conflict of interest.

\section{PODSUMOWANIE}

Terapia owrzodzeń skóry w SSc wymaga indywidualnego podejścia z uwzględnieniem nasilenia zmian chorobowych i współistniejących powikłań. Zawsze opiera się na zastosowaniu leczenia ogólnoustrojowego i miejscowego, w tym o działaniu przeciwbólowym, jak również metod niefarmakologicznych. Odpowiednia edukacja i zmiana stylu życia może się przyczynić do poprawy wyników terapii i zapobiegania nawrotom. Przy istotnym nasileniu objawów może być konieczna hospitalizacja i modyfikacja leczenia uwzględniająca ogólny stan pacjenta, postęp choroby oraz czynniki wpływające na jej przebieg.

\section{KONFLIKT INTERESÓW}

Autorka nie zgłasza konfliktu interesów.

\section{References}

\section{Piśmiennictwo}

1. Strange G., Nash P.: The manifestations of vasculopathy in systemic sclerosis and its evidence-based therapy. Int J Rheum Dis 2009, 12, 192-206.

2. Hachulla E., Clerson P., Launay D., Lambert M., Morell-Dubois S., Queyrel V., et al.: Natural history of ischemic digital ulcers in systemic sclerosis: single-center retrospective longitudinal study. J Rheumatol 2007, 34, 2423-2430.

3. LeRoy E.C., Medsger T.A. Jr.: Criteria for the classification of early systemic sclerosis. J Rheumatol 2001, 28, 1573-1576.

4. Meijs J., Voskuyl A.E., Bloemsaat-Minekus J.P., Vonk M.C.: Blood flow in the hands of predefined homogeneous systemic sclerosis population: the presence of digital ulcers and improvement with bosentan. Rheumatology (Oxford) 2015, 54, 262-269.

5. Valentini G., Marcoccia A., Cuomo G., Iudici M., Vettori S.: The concept of early systemic sclerosis following 2013 ACR EULAR criteria for the classification of systemic sclerosis. Curr Rheumatol Rev 2014, 10, 38-44.

6. Sunderkötter C., Herrgott I., Brückner C., Moinzadeh P., Pfeiffer C., Gerss J., et al.: Comparison of patients with and without digital ulcers in systemic sclerosis: detection of possible risk factors. Br J Dermatol 2009, 160, 835-843.

7. Hunzelmann N., Riemekasten G., Becker M.O., Moinzadeh P., Kreuter A., Melchers I.: The Predict Study: low risk for digital ulcer development in patients with systemic sclerosis with increasing disease duration and lack of topoisomerase- 1 antibodies. Br J Dermatol 2016, 174, 1384-1387.

8. Denton C.P., Krieg T., Guillevin L., Schwierin B., Rosenberg D., Silkey M., et al.: Demographic, clinical and antibody characteristics of patients with digital ulcers in systemic sclerosis: data from the DUO Registry. Ann Rheum Dis 2012, 71, 718-721.

9. Mihai C., Landewé R., van der Heijde D., Walker U.A., Constantin P.I., Gherghe A.M., et al.: Digital ulcers predict a worse disease course in patients with systemic sclerosis. Ann Rheum Dis 2016, 75, 681-686.

10. Amanzi L., Braschi F., Fiori G., Galluccio F., Miniati I., Guiducci S., et al.: Digital ulcers in scleroderma: staging, characteristics and sub-setting through observation of 1614 digital lesions. Rheumatology (Oxford) 2010, 49, 1374-1382.

11. Matucci-Cerinic M., Seibold J.R.: Digital ulcers and outcomes assessment in scleroderma. Rheumatology (Oxford) 2008, 47, v46-v47.

12. Ennis H., Vail A., Wragg E., Taylor A., Moore T., Murray A.A., et al.: Prospective study of systemic sclerosis-related digital ulcers: prevalence, location, and functional impact. Scand J Rheumatol 2013, 42, 483-486.

13. Valenzuela A., Baron M., Canadian Scleroderma Research Group, Herrick A.L., Proudman S., Stevens W.: Calcinosis is associated with digital ulcers and osteoporosis in patients with systemic sclerosis: a Scleroderma Clinical Trials Consortium study. Semin Arthritis Rheum 2016, 46, 344-349.

14. Gutierrez Jr. A., Wetter D.A.: Calcinosis cutis in autoimmune connective tissue diseases. Dermatol Ther 2012, 25, 195-206.

15. Balin S.J., Wetter D.A., Andersen L.K., Davis M.D.: Calcinosis cutis occurring in association with autoimmune connective tissue disease: the Mayo Clinic experience with 78 patients, 1996-2009. Arch Dermatol 2012, 148, 455-462.

16. Shanmugam V.K., Price P., Attinger C.E., Steen V.D.: Lower extremity ulcers in systemic sclerosis: features and response to therapy. Int J Rheumatol 2010, 2010, 747-946.

17. Shanmugam V.K., Schilling A., Germinario A., Mete M., Kim P., Steinberg J., et al.: Prevalence of immune disease in patients with wounds presenting to a tertiary wound healing centre. Int Wound J 2012, 9, 403-411.

18. Harrison B.J., Silman A.J., Hider S.L., Herrick A.L.: Cigarette smoking as a significant risk factor for digital vascular disease in patients with systemic sclerosis. Arthritis Rheum 2002, 46, 3312-3316.

19. Valenzuela A., Chung L.: Management of calcinosis associated with systemic sclerosis. Curr Treat Options Rheum 2016, 2, 85-96.

20. Asano Y., Sato S.: Vasculopathy in scleroderma. Semin Immunopathol 2015, 37, 489-500.

21. Hafner J, Schneider E., Burg G., Cassina P.C.: Management of leg ulcers in patients with rheumatoid arthritis or systemic sclerosis: the importance of concomitant arterial and venous disease. J Vasc Surg 2001, 32, 322-329. 
22. Alivernini S., De Santis M., Tolusso B., Mannocci A., Bosello S.L., Peluso G., et al.: Skin ulcers in systemic sclerosis: determinants of presence and predictive factors of healing. J Am Acad Dermatol 2009, 60, 426-435.

23. Parodi A., Drosera M., Barbieri L., Rebora A.: Antiphospholipid antibody system in systemic sclerosis. Rheumatology 2001, 40, 111-112.

24. Zandman-Goddard G., Tweezer-Zaks N., Shalev T., Levy Y., Ehrenfeld M., Langevitz P.: A novel overlap syndrome: systemic sclerosis associated with antiphospholipid syndrome: a case series. Ann N Y Acad Sci 2007, 1108, 497-504.

25. Giuggioli D., Manfredi A., Colaci M., Manzini C.U., Antonelli A., Ferri C.: Systemic sclerosis and cryoglobulinemia: our experience with overlapping syndrome of scleroderma and severe cryoglobulinemic vasculitis and review of the literature. Autoimmun Rev 2013, 12, 1058-1063.

26. Giuggioli D., Manfredi A., Lumetti F., Colaci M., Ferri C.: Scleroderma skin ulcers definition, classification and treatment strategies our experience and review of the literature. Autoimmun Rev 2018, 17, 155-164.

27. Giuggioli D., Manfredi A., Colaci M., Lumetti F., Ferri C.: Scleroderma digital ulcers complicated by infection with fecal pathogens. Arthritis Care Res 2012, 64, 295-297.

28. Giuggioli D., Manfredi A., Colaci M., Lumetti F., Ferri C.: Osteomyelitis complicating scleroderma digital ulcers. Clin Rheumatol 2013, 32, 623-627.

29. Blagojevic J., Piemonte G., Benelli L., Braschi F., Fiori G., Bartoli F., et al.: Assessment, definition, and classification of lower limb ulcers in systemic sclerosis: a challenge for the rheumatologist. J Rheumatol 2016, 43, 592-598.

30. Zhou A.Y., Muir L., Harris J., Herrick A.L.: The impact of magnetic resonance imaging in early diagnosis of hand osteomyelitis in patients with systemic sclerosis. Clin Exp Rheumatol 2014, 32, S232.

31. Frerix M., Stegbauer J., Dragun D., Kreuter A., Weiner S.M.: Ulnar artery occlusion is predictive of digital ulcers in SSc: a duplex sonography study. Rheumatology (Oxford) 2012, 51, 735-742.

32. Kato H., Watanabe S., Morita A.: Skin perfusion pressure is useful for evaluating digital ulcer caused by systemic sclerosis. J Dermatol 2012, 39, 4812.

33. Hughes M., Ong V.H., Anderson M.E., Hall F., Moinzadeh P., Griffiths B.: Consensus best practice pathway of the UK Scleroderma Study Group: digital vasculopathy in systemic sclerosis. Rheumatology 2015, 54, 2015-2024.

34. Fiori G., Galluccio F., Braschi F., Amanzi L., Miniati I., Conforti M.L., et al.: Vitamin E gel reduces time of healing of digital ulcers in systemic sclerosis. Clin Exp Rheumatol 2009, 27, 51-54.

35. Krasowska D., Rudnicka L., Dańczak-Pazdrowska A., Chodorowska G., Woźniacka A., Lis-Święty A., et al.: Twardzina układowa - rekomendacje diagnostyczno-terapeutyczne Polskiego Towarzystwa Dermatologicznego. Część 2: leczenie. Dermatol Rev/Przegl Dermatol 2017, 104, 583-596.

36. Kowal-Bielecka O., Landewé R., Avouac J., Chwiesko S., Miniati I., Czirjak L., et al.: EULAR recommendations for the treatment of systemic sclerosis. Ann Rheum Dis 2009, 68, 620-628.

37. Morrisroe K., Frech T., Schniering J., Maurer B., Nikpour M.: Systemic sclerosis: the need for structured care. Best Pract Res Clin Rheumatol 2016, 30, 3-21.

38. Tingey T., Shu J., Smuczek J., Pope J.: Meta-analysis of healing and prevention of digital ulcers in systemic sclerosis. Arthritis Care Res (Hoboken) 2013, 65, 1460-1471

39. Ferreira M.E., Scheinberg M.A.: Successful treatment with bosentan of non-digital skin ulcers in severe scleroderma. Ann Rheum Dis 2008, 67, 1784-1785.

40. Taniguchi T., Asano Y., Hatano M., Tamaki Z., Tomita M., Kawashima T., et al.: Effects of bosentan on nondigital ulcers in patients with systemic sclerosis. Br J Dermatol 2012, 166, 417-421.

41. Richetta A.G., Mattozzi C., Maiani E., D’Epiro S., Cimillio M., Carboni V., et al.: Efficacy of bosentan in treatment of refractory sclerodermic bone prominences skin ulcers. Clin Ter 2008, 159, 317-319.

42. Naert A., De Haes P.: Successful treatment with bosentan of lower extremity ulcers in a scleroderma patient. Case Rep Med 2013, 2013, 690591.

43. Abou-Raya A., Abou-Raya S., Helmii M.: Statins: potentially useful in therapy of systemic sclerosis-related Raynaud's phenomenon and digital ulcers. J Rheumatol 2008, 35, 1801-1808.

44. Khor C.G., Chen X.L., Lin T.S., Lu C.H., Hsieh SC.: Rituximab for refractory digital infarcts and ulcers in systemic sclerosis. Clin Rheumatol 2014, 33, 1019-1020.

45. Daoussis D., Antonopoulos I., Liossis S.N., Yiannopoulos G., Andonopoulos A.P.: Treatment of systemic sclerosis-associated calcinosis: a case report of rituximab-induced regression of CREST-related calcinosis and review of the literature. Semin Arthritis Rheum 2012, 41, 822-829.

46. Gualtierotti R., Adorni G., Lubatti C., Zeni S., Meroni P.L., Ingegnoli F.: Digital ulcer management in patients with systemic sclerosis. OA Arthritis 2014, 2, 2.

47. Shanmugam V.K.: Vasculitic diseases and prothrombotic states contributing to delayed healing in chronic wounds. Curr Dermatol Rep 2016, 5, 270-277.

48. Giuggioli D., Manfredi A., Vacchi C., Sebastiani M., Spinella A., Ferri C.: Procedural pain management in the treatment of scleroderma digital ulcers. Clin Exp Rheumatol 2015, 33, 5-10.

49. Barsotti S., Mattaliano V., d'Ascanio A., Mosti G., Della Rossa A., Mattaliano C., et al.: Systemic sclerosis chronic ulcers: preliminary results of treatment with allogenic skin grafting in a cohort of Italian patients. Int Wound J 2016, 13, 1050-1051.

50. Arhuidese I., Malas M., Obeid T., Massada K., Khaled A., Alzahrani A., et al.: Outcomes after open infrainguinal bypass in patients with scleroderma. J Vasc Surg 2016, 64, 117-123.

51. Momeni A., Sorice S.C., Valenzuela A., Fiorentino D.F., Chung L., Chang J.: Surgical treatment of systemic sclerosis - is it justified to offer peripheral sympathectomy earlier in the disease process? Microsurgery 2015, 35, 441-446.

52. Motegi S.I., Sekiguchi A., Saito S., Ishibuchi H., Kishi C., Yasuda M., et al:. Successful treatment of Raynaud's phenomenon and digital ulcers in systemic sclerosis patients with botulinum toxin B injection: assessment of peripheral vascular disorder by angiography and dermoscopic image of nail fold capillary. J Dermatol 2018, 45, 349-352. 
53. Bello R.J., Cooney C.M., Melamed E., Follmar K., Yenokyan G., Leatherman G., et al.: The therapeutic efficacy of botulinum toxin in treating scleroderma-associated Raynaud's phenomenon: a randomized, double-blind, placebo-controlled clinical trial. Arthritis Rheumatol 2017, 69, 1661-1669.

54. Moran M.E.: Scleroderma and evidence based non pharmaceutical treatment modalities for digital ulcers: a systematic review. J Wound Care 2014, 23, 510-516.

Received: 13.05 .2018

Accepted: 23.07 .2018

Otrzymano: $13.05 .2018 \mathrm{r}$.

Zaakceptowano: $23.07 .2018 \mathrm{r}$.

How to cite this article

Lis-Święty A.: Skin ulcers in systemic sclerosis - etiopathogenesis, prophylaxis and treatment. Dermatol Rev/Przegl Dermatol 2018, 105, 509-522. DOI: https://doi.org/10.5114/dr.2018.78072. 